\title{
SISTEM PENDUKUNG KEPUTUSAN MODEL PENENTUAN SISWA TELADAN PADA SMK BONAVITA DENGAN PENDEKATAN LOGIKA FUZZY
}

\author{
Dedy Iskandar $^{1}$,Taviv Prahasta ${ }^{2}$, Ardi Rahmadani $^{3}$ \\ 1,2,3 Jl. Jendral SudirmanNo. 40, Modernland, Tangerang \\ Email : ${ }^{1}$ iskandar@ raharja.info, ${ }^{2}$ tavip@ raharja.info, ${ }^{3}$ ardi.rahmadani@ raharja.info
}

\begin{abstract}
ABSTRAK
Sekolah adalah suatu lembaga yang bukan hanya mengajarkan ilmu pengetahuan atau tempat menuntut ilmu tetapi yang sangat penting adalah mendidik siswa/siswi. Pendidikan tersebut akan mempengaruhi atau dapat merubah tingkah laku, akhlak, kepribadian, cara berfikir, kedewasaan dan lain-lain, karena dengan pendidikan tersebut diharapkan siswa/siswi sebagai anak didik bukan hanya memahami atau menguasai ilmu dan teknologi tetapi juga mempunyai akhlak dan kepribadian yang baik. Tujuan pendidikan nasional disebut juga tujuan umum adalah tujuan pendidikan yang ingin dicapai pada tingkat nasional. Untuk negara Indonesia, tujuan pendidikan nasional tercantum dalam Undang Undang RI No. 2 Tahun 1989 tentang Sistem Pendidikan Nasional pada Bab II, Pasal 4 yang berbunyi: "Pendidikan Nasional mencerdaskan kehidupan bangsa dan mengembangkan manusia Indonesia seutuhnya, yaitu manusia yang beriman dan bertakwa terhadap Tuhan Yang Maha Esa dan berbudi pekerti luhur, memiliki pengetahuan dan ketrampilan, kesehatan jasmani dan rohani, kepribadian yang mantap dan mandiri serta rasa tanggung jawab kemasyarakatan dan kebangsaan. Untuk mewujudkan tujuan pendidikan nasional,visi dan misi sekolah maka sekolah perlu memilih seorang siswa yang akan dijadikan teladan atau contoh bagi siswa lainnya dalam belajar, tingkah laku, sikap, dan bersosialisasi dalam lingkugan sekolahnya atau luar sekolah (masyarakat). agar dapat diwujudkan siswa teladan tersebut maka kepala sekolah dan para guru membuat kriteria/persyaratan untuk menentukan siswa dianggap sebagai siswa teladan. Untuk menentukan siswa teladan tersebut maka salah satu pendekatan yang dapat dilakukan dengan menggunakan logika fuzzy. Dan kriteria penilaian dapat dilakukan dengan melihat sikap, kedisiplinan, nilai rata-rata raport, organisasi, nilai praktek kerja lapangan, kerapihan dan terlibat narkoba dan barang terlarang. Dengan pendekatan tersebut diharapkan mampu memilih siswa teladan dengan efektif. Dari kriteria tersebut maka dibuatlah suatu sistem pendukung keputusan untuk menentukan siswa teladan tersebut.
\end{abstract}

Kata Kunci : Sistem Pendukung Keputusan, Siswa Teladan, Logika Fuzzy

\begin{abstract}
School is an institution that not only teach science or study but also is very important to educate the students. The education will influence or change the behavior, character, personality, way of thinking, maturity and etc, because the education is expected the student not only understand or master of science and technology but also have good character and personal. National education goals also called general purpose is education goals to be achieved at the national level. Indonesia's national education goals listed in law Republic Indonesia number 2 1989, about the national education system chapter 2 verse 4 said: national education the nation and develop human whose faith and fear of God, good character, knowledge and skills, physical and spiritual health, personality and independence and sense responsibility for society and nationality. To achieve national education goals, vision and mission of the school, the scholl students need to choose someone who can be role model for other students in learning, behavior, attitudes and how to interact in school or outside the school cenvironment. The head master and the teacher make the criteria or requirements to determine who will be role model and they use an approach that can be done by using Fuzzy logic. And the assesment's criteria can be done by looking at the attitude, discipline, the average of mark, the organization, and involved in drugs. That approached is expected to choose a role model of student effectively. From that criteria they make a decision support system to determine thet role mode student.
\end{abstract}

Key words : decision support system, a role , model student, Fuzzy Logic 


\section{PENDAHULUAN}

Sekolah adalah suatu lembaga yang bukan hanya mengajarkan ilmu pengetahuan atau tempat menuntut ilmu tetapi yang sangat penting adalah mendidik siswa/siswi. Pendidikan tersebut akan mempengaruhi atau dapat merubah tingkah laku, akhlak, kepribadian, cara berfikir, kedewasaan dan lain-lain, karena dengan pendidikan tersebut diharapkan siswa/siswi sebagai anak didik bukan hanya memahami atau menguasai ilmu dan teknologi tetapi juga mempunyai akhlak dan kepribadian yang baik. Pendidikan adalah usaha sadar dan bertujuan untuk mengembangkan kualitas manusia. Sebagai suatu kegiatan yang sadar akan tujuan, maka dalam pelaksanaanya berada dalam suatu proses yang berkesinambungan dalam setiap jenis dan jenjang pendidikan. Semuanya berkaitan dalam suatu sistem pendidikan yang integral. Pendidikan sebagai suatu sistem, tidak lain dari suatu totalitas fungsional yang terarah pada nsuatu tujuan. Setiap subsistem yang ada dalam sistem tersusun dan tidak dapat dipisahkan dari rangkaian unsur-unsur atau komponen-komponen yang berhubungan secara dinamis dalam suatu kesatuan.

\section{RUMUSAN MASALAH}

Masalah yang akan dibahas dan dianalisis penulis adalah :

"Seperti apa membuat Sistem Pendukung Keputusan untuk menentukan siswa teladan dengan pendekatan logika fuzzy “.

\section{RUANG LINGKUP}

Topik mengenai penentuan siswa teladan pada suatu sekolah memang bermacam-macam tergantung ketentuan sekolah masing-masing. Dalam penulisan ini untuk menentukan siswa teladan dengan menggunakan pendekatan logika fuzzy. Penelitian dilakukan pada SMK Bonavita Tangerang dengan periode waktu analisis antara tahun 2014 sampai dengan tahun 2015 atau data yang dianilisis adalah data siswa yang dimulai dari kelas 1 sampai kelas 2 dan menginjak dikelas 3 adalah penentuan siswa teladannya. Kriteria penilaian dapat dlihat dari sikap, kedisiplinan, nilai rata-rata raport, organisasi, nilai praktek kerja lapangan, kerapihan, terlibat narkoba dan barang terlarang, yang akan dijadikan variabel fuzzy dalam prosesnya.

\section{TUJUAN PENELITIAN}

Mengaplikasikan logika fuzzy untuk membantu dalam menentukan suatu keputusan pada tingkat manajemen. Bagi Kepala Sekolah sebagai pembuat keputusan memudahkan untuk menentukan siswa teladan pada sekolah yang dipimpinnya.

\section{MANFAAT PENELITIAN}

Bagi lembaga pendidikan yaitu sebagai pengembangan ilmu pengetahuan khususnya dibidang logika fuzzy dan penerapan logika fuzzy dalam kehidupan sehari-hari.

\section{METODE PENELITIAN}

Dalam metodologi penelitian ini menggunakan metode - metode sebagai berikut :

\section{A. Metode pengumpulan data}

Metode pengumpulan data ini terdiri atas :

1. Pengamatan Langsung (Observasi) yaitu pengumpulan data - data dengan cara pengamatan langsung terhadap kegiatan - kegiatan yang sedang dilakukan untuk mengetahui permasalahan yang terjadi pada sistem berjalan.

2. Wawancara (Interview) yaitu ini penulis melakukan tanya jawab secara langsung dengan pihak yang terkait seperti pembina, pengurus, dan yang sudah menjadi anggota guna mendapatkan informasi yang jelas, akurat dan tepat.

3. Studi Pustaka (Library Research) yaitu upaya penulis mencari dan mengumpulkan data pendukun dari buku - buku atau makalah yang berhubungan dengan permasalahan yang dibahas penelitian ini sebagai panduan dan referensi.

\section{B. Metode analisa data}

Dalam metode ini menggunakan analisis SWOT (Strength, Weakness, Opportunity, Threat) untuk mengetahui kekuatan internal dan eksternal yayasan, sedangkan untuk menganalisis program yang sedang berjalan menggunakan Unified Modelling Language (UML) sebagai alat bantu yang dapat digunakan dalam bahasa pemrograman yang berorientasi objek. 


\section{Metode prototyping}

Alasan penulis menggunakan metode prototyping ini adalah bahwa prototype adalah bentuk fisik pertama dari satu objek yang direncanakan dibuat dalam satu proses produksi, mewakili bentuk dan dimensi dari objek yang diwakilinya dan digunakan untuk objek penelitian dan pengembangan lebih lanjut. Jadi dengan menggunakan metode ini penelitian dapat selesai tepat waktu

\section{LITERATURE REVIEW}

Berikut ini adalah beberapa penelitian yang telah dilakukan dan memiliki korelasi yang serupa dengan penelitian ini:

1. Dalam International Journal of Economics and Management Sciences Vol 1 No.5 (2011), yang berjudul Impact of Perceived Value on Word of Mouth Endorsement and Customer Satisfaction : Mediating Role of Repurchase Intentions, menyatakan bahwa penelitian ini menemukan bahwa kepuasan konsumen akan berdampak kepada minat konsumen untuk datang kembali. Hasil pengaruh regresi menunjukkan bahwa kepuasan konsumen secara positif berpengaruh terhadap repurchase behavior.

2. Dalam Journal of Sport Management (2010), Vol 24, hal 83-105, yang berjudul Beragam Cara untuk Melakukan Pembelian Kembali, Studi Kasus Industri Kesehatan dan Kebugaran, menyatakan dalam penelitian ini meneliti kepuasan konsumen terhadap repurchase intention pada Gym. Hasil menunjukkan bahwa kepuasan konsumen (overall satisfaction) tidak berpengaruh terhadap repurchase intention.

3. Dalam jurnal yang berjudul Pengaruh Persepsi Kualitas Pelayanan, Kualitas Produk dan Harga terhadap Loyalitas Pelayanan Flexi di Kota Semarang dengan Intervening Kepuasan Pelayanan Vol 12, No. 1 (2010), menyatakan bahwa penelitian ini membahas dan mempertahankan pelanggan kita perlu menciptakan loyalitas pelanggan dengan meningkatkan kualitas dengan intervening dan kualitas produk dan harga.

\section{Analisa Deskritif}

\section{HASIL DAN PEMBAHASAN}

Analisa deskritif yang dilakukan dalam penelitian ini meliputi : (i) Analisis Frekwensi, (ii) Analisis ukuran pemusatan, dan (iii) analisis penyebaran. Berikut ini pembahasan analisis deskritif data yang dikumpulkan dikategorikan berdasarkan : umur, jenis kelamin, pekerjaan orang tua, sikap, kedisiplinan, kerapihan, narkoba dan barang terlarang, rata-rata rapor, nilai praktek kerja lapangan dan organisasi.

1. Analisis Umur

Siswa yang masuk tahun 2014 dan lulus tahun 2016 umurnya berkisar antara 18 tahun sampai dengan 20 Tahun

\section{Tata laksana sistem yang berjalan}

\section{Input Data Siswa}

Pada tahap pertama ini adalah tahap memasukkan data identitas siswa terdiri dari NO, NIS, Nama Siswa, Tgl Lahir, Jenis, Jenis Kelamin, Alamat, Kota, Nama Orang Tua, Pekerjaan.

Desain input data siswa dapat dilihat pada Gambar berikut.

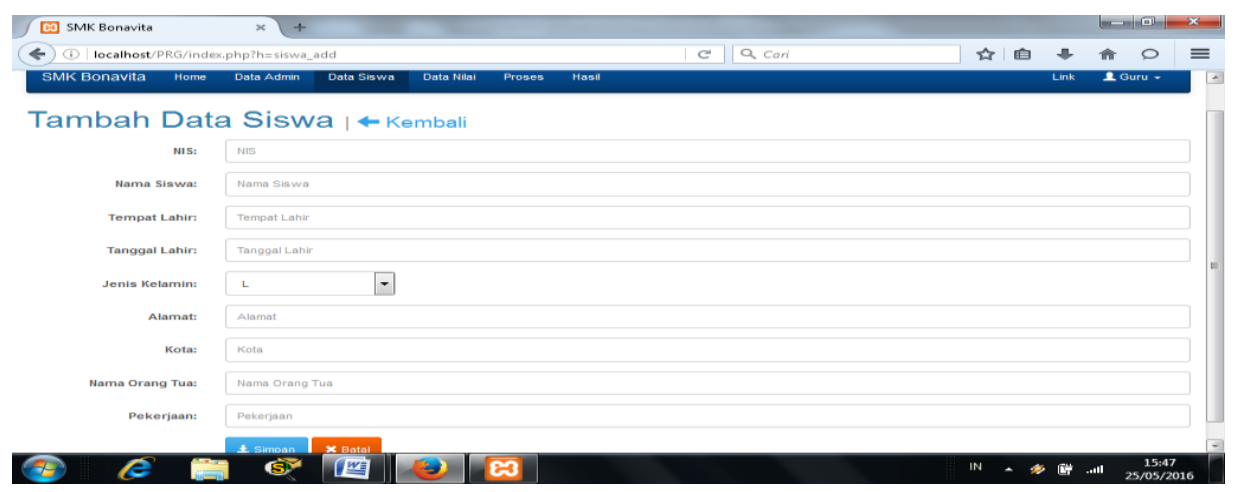




\section{Desain Input Data Siswa}

\section{Input Bobot Nilai Kriteria Siswa}

Tahap ini adalah tahap memasukkan data bobot nilai kriteria siswa yang terirdiri dari NIS, Nama Siswa, Sikap, Displin, Rapih, Narkoba, Rapor, Nilai Pkl, Organisasi. Desain input bobot Nilai Kriteria Siswa dapat dilihat pada Gambar berikut
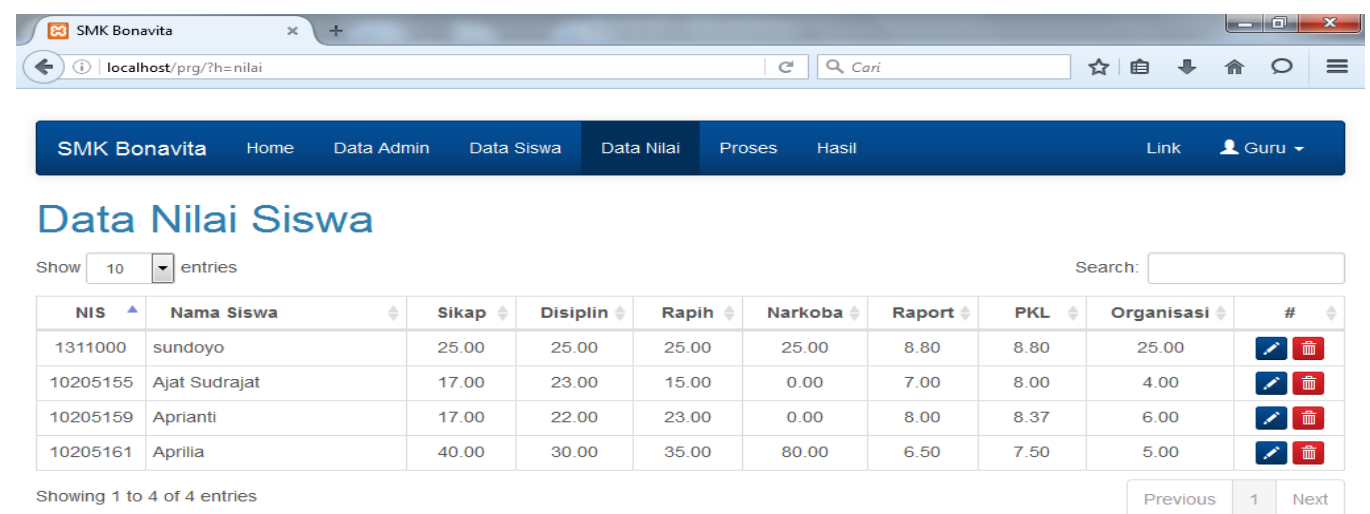

A. (2) Q e

\section{Input Nilai Kriteria Siswa}

\section{Proses Fire Strength Kriteria}

Pada tahap ini adalah proses operasi himpunan fuzzy yang terdiri dari sikap dengan himpunan baik, kedisiplinan dengan himpunan baik, kerapihan dengan himpunan baik, narkoba dengan himpunan tidak terlibat, nilai rapor dengan himpunan baik, nilai pkl dengan himpunan baik dan organisasi dengan himpunan aktif.

Desain output proses penghitungan fire strength dapat dilihat pada gambar berikut:

\section{Variabel Kerapihan}
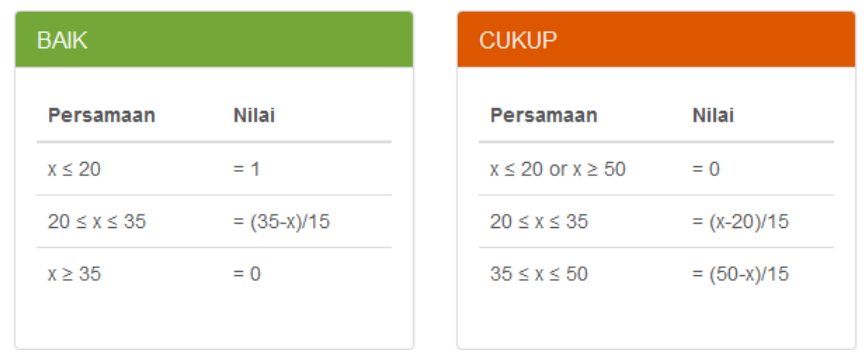

\section{BURUK}

\begin{tabular}{ll} 
Persamaan & Nilai \\
\hline$x \leq 35$ & $=0$ \\
$35 \leq x \leq 50$ & $=(x-35) / 15$ \\
$x \geq 50$ & $=1$
\end{tabular}

Gambar Output Proses Penghitungan Fire Strength 
Variabel Narkoba dan Obat Terlarang

\begin{tabular}{ll} 
TIDAK TERLIBAT & Nilai \\
\hline Persamaan & $=1$ \\
\hline$x \leq 0$ & $=(30-x) / 30$ \\
\hline$x \geq 3 \leq 30$ & $=0$ \\
\end{tabular}

\section{TERLIBAT}

\begin{tabular}{ll} 
Persamaan & Nilai \\
\hline$x \leq 20$ & $=0$ \\
$20 \leq x \leq 80$ & $=(x-20) / 60$ \\
$x \geq 80$ & $=1$
\end{tabular}

Gambar Output Proses Penghitungan Fire Strength

\section{Variabel Rata-rata Nilai Raport}

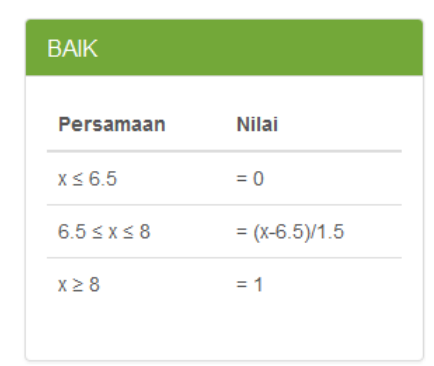

\begin{tabular}{ll} 
CUKUP & \\
Persamaan & Nilai \\
\hline$x \leq 6$ or $x \geq 8$ & $=0$ \\
$6 \leq x \leq 7$ & $=x-6$ \\
$7 \leq x \leq 8$ & $=8-x$
\end{tabular}

\begin{tabular}{|ll}
\hline BURUK & \\
\hline Persamaan & Nilai \\
\hline$x \leq 5.5$ & $=1$ \\
\hline $5.5 \leq x \leq 6.5$ & $=6.5-x$ \\
\hline$x \geq 6.5$ & $=0$ \\
\end{tabular}

\section{Gambar Output Proses Penghitungan Fire Strength}

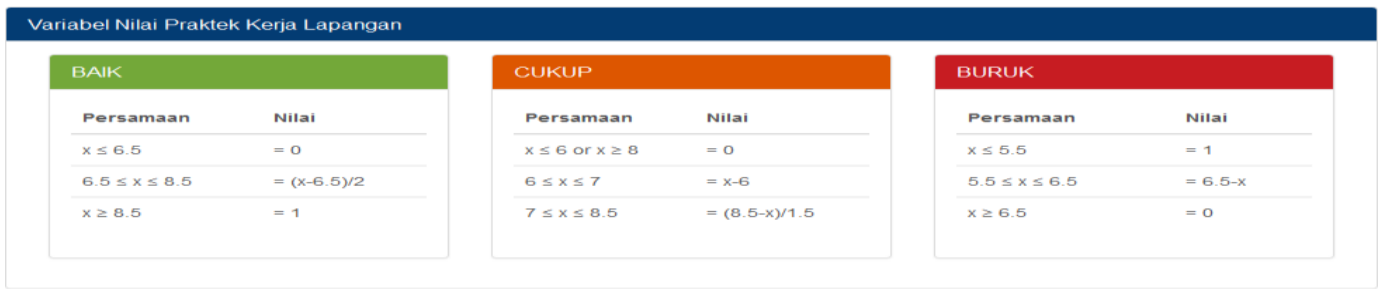

Gambar Output Proses Penghitungan Fire Strength

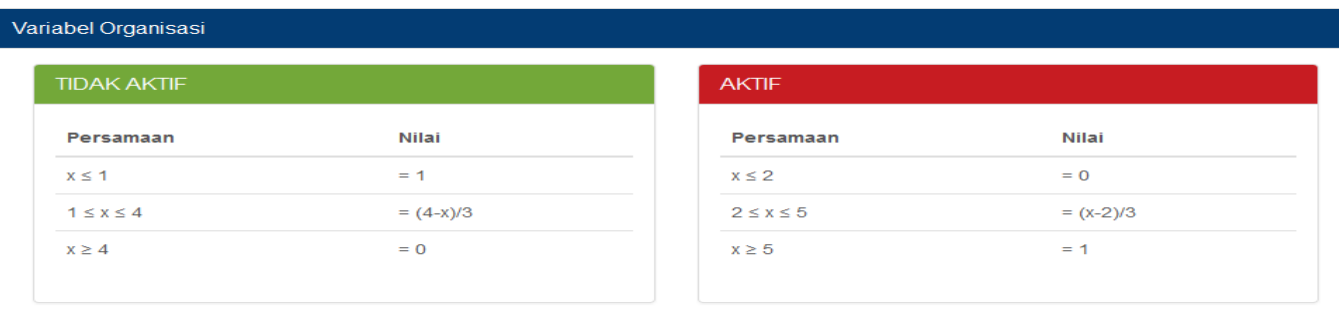

Gambar Output Proses Penghitungan Fire Strength

\section{KESIMPULAN}

1. Penentuan siswa teladan dengan sistem pendukung keputusan dengan pendekatan logika fuzzy lebih objektif dari pada penentuan siswa teladan cara manual.

2. 7 kriteria yang dijadikan variabel fuzzy mempunyai himpunan fuzzy : baik, cukup, buruk, aktif, tidak aktif, terlibat dan tidak terlibat.

3. Sistem pendukung keputusan dengan pendekatan logika fuzzy merekomendasikan siswa teladan dengan menghitung fire strength, dimana fire strength harus lebih besar sama dengan 0.6 . 


\section{DAFTAR PUSTAKA}

[1]. Henderi, Maimunah, Randy Andriyan. 2011. Desain Aplikasi E-learning Sebagai Media Pembelajaran Artificial Informatics. Tangerang: Jurnal CCIT. Vol. 4, No.3-Mei 2011.

[2]. Henderi, Maimunah, Randy Andriyan. 2011. Desain Aplikasi E-learning ebagai

[3]. Media Pembelajaran Artificial Informatics. Tangerang: Jurnal CCIT. Vol.4, No.3-Mei 2011.

[4]. Nasaruddin, Djafar Imran dan Samsie Indra. 2013. Perancangan Sistem Informasi Supply Chain Management (SCM) Pada CV Rajawali Multi Niaga Makassar. Tangerang: Jurnal CCIT Vol.6 No.2, 226-227.

[5]. Nugroho, Adi. 2010. Rekayasa Perangkat Lunak Menggunakan UML \& Java. Yogyakarta: Andi Offset.

[6]. Nugroho, Adi. 2011. Perancangan dan Implementasi Sistem Basis Data. Yogyakarta: CV. Andi Offset.

[7]. Nazrudin, Safaat H. (2012 : 9) Perangkat Lunak Aplikasi elib.unikom.ac.id/download.php?id=246792 Sekolah Teknik Elektro dan Informatika (STEI), Institut Teknologi Bandung (ITB) angkatan 2010.

[8]. Oktavian, Diar Puji. 2010. Menjadi Programmer jempolan menggunakan PHP. Yogyakarta: Mediakom.

[9]. Prabowo Pudjo Widodo. 2011. Menggunakan UML. Bandung: Informatika.

[10]. Rahardja Untung, Hidayati, Mia Novalia. 2011. Peningkatan Kerja Distributed Database Melalui Metode DMQ Base Level. Jurnal CCIT Vol-4 No-3-mei 2011.

[11]. Ranggagading, Volume 11, Nomor 1. April 2011, hal. 41-48.

[12]. Sutabri, Tata. 2012. Konsep Dasar Informasi. Yogyakarta: Andi Offset.

[13]. Sutarman. 2012. Buku Pengantar Teknologi Informasi. Jakarta: Bumi Aksara.

[14]. Sinambela (2010, hal : 3) https://emayasila.wordpress.com/2012/10/17/teoripelayanan/

[15]. Sinambela, L.P. 2010. Reformasi Pelayanan Publik; Teori, Kebijakan dan. Implementasi, cetakan kelima Jakarta: PT. Bumi Aksara.

[16]. Sunyoto http://www.woodpress.com/ Kepuasan Konsumen. diakses tanggal 05 Oktober 2011.

[17]. Sujana dan Zebua, Amenesi. 2011. Pengaruh Pelayanan Terhadap Loyalitas Pelanggan (Study Kasus Pada PT. Setia Anugerah Motor). Jurnal Ilmiah

[18]. Tanti, Lili. 2010. Pengembangan Perangkat Ajar Berbantuan Komputer Untuk Mempelajari Tata Bahasa Inggris. Tangerang: Jurnal CCIT Vol.3 No.2 (2010:208).

[19]. Taufiq, Rohmat. 2013. Sistem Informasi Manajemen. Yogyakarta: Graha Ilmu.

[20]. Tuban, E . 2010. Electronic Commerce: A Managerial Perspective. New Jersey: Pearson Prentice Hall, inc. 